The University of Southern Mississippi The Aquila Digital Community

Faculty Publications

9-1-2010

\title{
Theme-Based Instruction: Making Conceptual Ties with the Sickle Cell Story
}

\author{
Sherry S. Herron \\ University of Southern Mississippi, sherry.herron@usm.edu \\ John Parr
}

Bridgette Davis

Parker Nelson

Follow this and additional works at: https://aquila.usm.edu/fac_pubs

Part of the Science and Mathematics Education Commons

\section{Recommended Citation}

Herron, S. S., Parr, J., Davis, B., Nelson, P. (2010). Theme-Based Instruction: Making Conceptual Ties with the Sickle Cell Story. American Biology Teacher, 72(7), 422-426.

Available at: https://aquila.usm.edu/fac_pubs/8381 


\section{ARTICLE}

\section{Theme-Based Instruction: Making}

Conceptual Ties with the

Sickle Cell Story

- SHERRY S. HERRON, JOHN PARR, BRIDGETTE DAVIS, PARKER NELSON

\section{Abstract}

We describe the concepts and resources presented during a workshop offered to high school biology teachers using sickle cell disease as a theme in a biology course. We provide their pretest and posttest results and reactions.

Key Words: Theme-based instruction; sickle cell disease; guided inquiry; bioinformatics; physiology; stem cells.

We believe that biology teachers can take advantage of lessons previously published in The American Biology Teacher and the new fields of bioinformatics and proteomics to create a course or unit based on the sickle cell story that covers multiple topics and uses a variety of teaching strategies. We first incorporated sickle cell disease (SCD) as one of the themes in a college laboratory course at a university where students could work in the sickle cell research center. While developing course materials, we became familiar with the common but oversimplified, and often obsolete, presentation of SCD in textbooks. As a disease of many "firsts," SCD has been incorporated into biology curricula for decades, but cartoon-like illustrations fail to communicate the vast amount of information associated with it.

Most teachers will agree that students respond positively to topics that demonstrate genuine usefulness. Sadly, the high incidences of SCD make the disease personally relevant in schools with large African-American or Arab populations. Like many others, we have taught students with SCD. The gene frequency of the sickle cell allele among African Americans is around 8\% (Beutler et al., 2001). This number equates to approximately 80,000 Americans suffering from the disease

Sadly, the high incidences of SCD make the disease personally relevant in schools with large African-American or Arab populations.
We wondered what high school teachers would think about giving more attention to the subject in the biology classroom some 30 years later.

The workshop described here provided an opportunity to discover how biology teachers would feel about a more focused coverage of the topic than is typically seen. The bulk of this article describes the concepts and activities that were used in the creation of a thematic unit found within past issues of The American Biology Teacher, Web site resources, and commercially available products. Despite extensive coverage of the topic, a thematic unit in biology has not been compiled. Some of the connections between SCD and other topics are shown in Figure 1.

\section{Methods}

An extensive study of instructional uses of SCD was undertaken in preparation for a 1-day workshop for biology teachers. The workshop was held in April 2008 at a comprehensive university located in the southeastern United States. A 30-item multiple-choice test was administered at the beginning and end of the day. Additionally, the teachers responded to five open-ended prompts designed to ascertain their feelings about the topic: I expected..., I got..., A thing of value..., I wish..., and Next I will.... Finally, the teachers completed an evaluation of the workshop, and a summary of their feedback was created.

In keeping with constructivist learning theory, we believe that it is essential to provide students the means to build their own conceptual understanding. Using traditional, high-tech, expensive equipment in the biology laboratory may actually communicate the esotericism of science more than it promotes real comprehension. Thus, during the workshop, the teachers built their own electrophoresis chambers inspired by the Access Excellence activity and visited stations that contained both printed materials and manipulatives related to $S C D$, guided by questions to answer. Materials came from the first author's general biology course, Howe's (2007) work promoting the use of SCD to teach the nature and process of science, science supply companies, the Internet, books, and articles. Various diagrams, illustrations, graphs, and maps printed in color were laminated and displayed at the 10 stations. Artifacts or manipulatives at individual stations included the following ( $\mathrm{CAP}=$ commercially available product): 


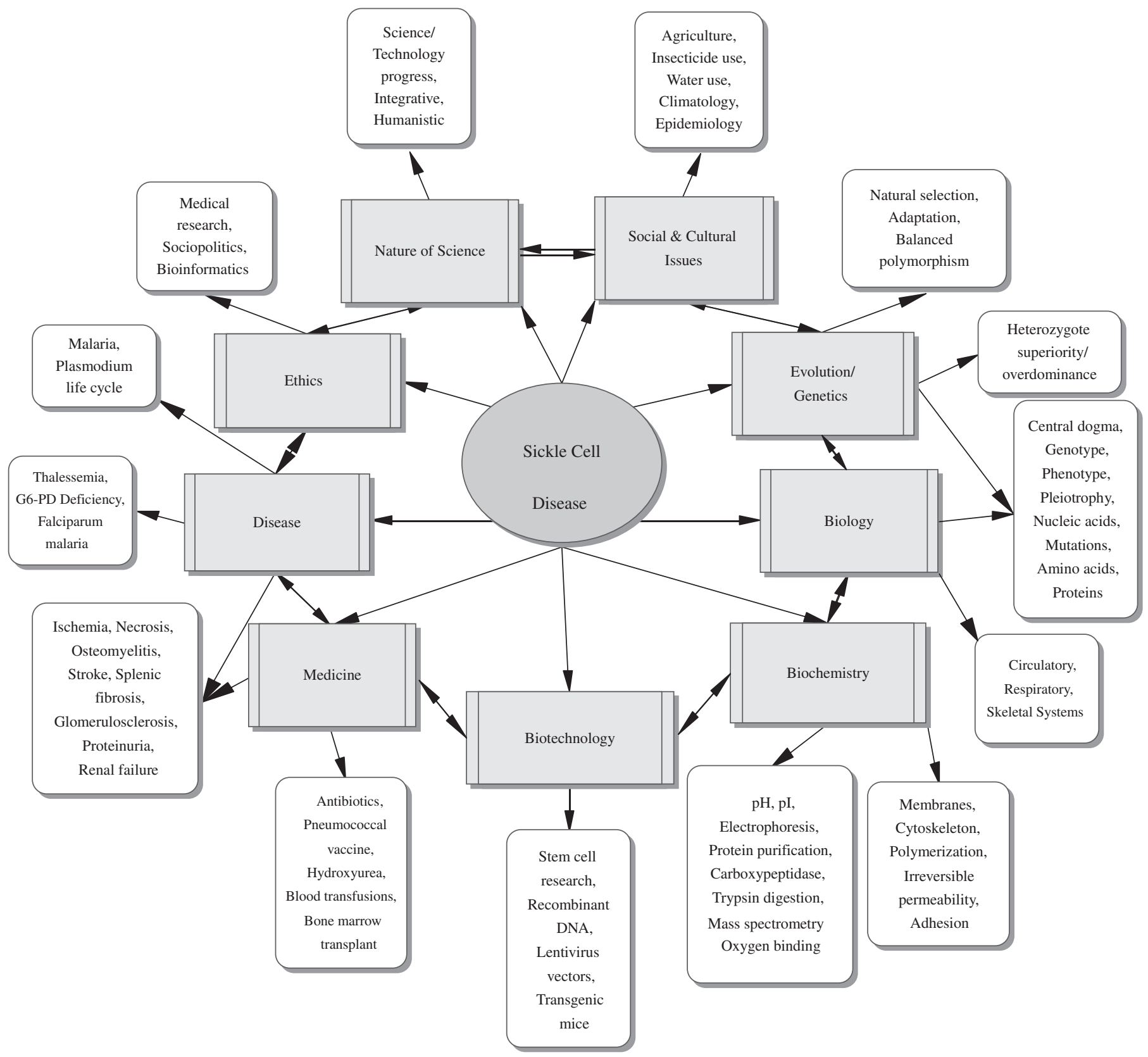

Figure 1. Potential connections of sickle cell disease to a variety of common topics used in education.

- Microscopes focused on prepared slides of blood

- Poster of the human circulatory system

- Bags containing beans, bags containing tongue depressors, and tubes large enough for the bean bags to pass through

- Spring-shaped pipe cleaners to build a hemoglobin protein

- Protein synthesis models for student manipulation and labeling (CAP)

- Hemoglobin sequence maps (CAP)

- Restriction-enzyme and plasmid manipulatives (CAP)

Before reading the participants' electrophoresis results, the instructor gave a PowerPoint presentation during which concepts highlighted at each station were discussed and further explained (the PowerPoint file can be downloaded at http://www.usm.edu/csme/ teacherstopic.htm).

\section{$\bigcirc$ Results}

\section{Overview of Sickle Cell \& Cell Structure}

When envisioning the cell, biology students are invariably presented images of a circular animal cell with the prerequisite parts: mitochondria, nucleus, ribosomes, et cetera. This will almost certainly be compared and contrasted with the perfectly rectangular plant cell. A discussion of healthy erythrocytes and those affected by SCD provides the basis for an expansion of this narrow concept. Students will likely be surprised to learn that circulating erythrocytes do not even contain a nucleus and could be described as cell membranes filled with hemoglobin (Bloom, 1995). This information can help students understand stem cells and conceptually recognize the necessity of cell differentiation.

Because the function of hemoglobin is to deliver oxygen and remove carbon dioxide, the study of respiration ties into the study of SCD. Creative teachers can develop skits to help students learn this process. In addition, 
the emerging field of proteomics offers resources that can help teachers convey the interactions of genes and proteins. For example, Biocarta, a biopharmaceutical company, has a Web site that presents interactive maps of metabolic pathways (indexed at http://www.biocarta.com/genes/ allPathways.asp), including Glycolysis Pathway (http://www.biocarta.com/ pathfiles/h_glycolysisPathway.asp) and Electron Transport Reaction in Mitochondria (http://www.biocarta.com/pathfiles/h_etcPathway.asp).

\section{Genetics \& Heredity}

Sickle cell disease was the first disease to be recognized as having a genetic basis, and thus linked phenotype to genotype (Weatherall \& Clegg, 2001). It was later determined that the expression of the alleles at a single location on the short arm of chromosome 11 (specifically, $11 \mathrm{p} 15.5)$ is responsible for determining the condition of the beta-globin polypeptide (Segal et al., 2008). The gene provides the template for the production of beta globin. The alpha-globin gene, located at 16p13.3, provides the template for alpha globin. Two beta globins and two alpha globins combine with heme to form human adult hemoglobin, Hb A. At least 476 beta-globin gene variants exist, and some result in life-threatening illnesses such as SCD, thalassemia, and ovalocytosis (Ashley-Koch et al., 2000). The single-gene nature of SCD makes it useful for a study of Mendelian genetics (Mertens \& Pursifull, 1986). Such a lesson invariably involves the use of the Punnett square (Barman et al., 1985).

Teachers may be unaware of the codominant nature of SCD, but it is estimated that approximately $30 \%$ of the erythrocytes will sickle in heterozygous individuals, those with sickle cell trait (SCT; Gordon, 2000). This presents an example of the tentative nature of science, as SCD was previously believed to be a dominant/recessive condition. Individuals with SCT are typically affected only in situations of dehydration or when the oxygen saturation falls to about one-third the normal level (Dispenzieri, 2001).

Genetic diseases are often used to introduce students to the use of pedigrees (DeRosa \& Wolfe, 1999). Sickle cell disease offers students the opportunity to discover their own pedigrees or those of modern individuals such as jazz king Miles Davis, rather than focusing on the common and less current lineage of Queen Victoria.

\section{DNA \& Protein Structure}

The central dogma can be illustrated with SCD as students discover the DNA sequences responsible for the normal, sickle, and thalassemia conditions using the commercially available hemoglobin maps. Thalassemia is a disorder that alters the number of hemoglobin molecules rather than the shape of the erythrocytes (Weatherall \& Clegg, 2001). Vigue (1987) discusses the genetic aspects of several mutations in the human beta-globin gene and illustrates the changes in the DNA code leading to each blood disease. Students are able to observe the possible consequences and variations to the processes of transcription and translation that result from a single incorrect base (Offner, 1992; Mulvihill, 1996). Lego blocks (Templin \& Fetters, 2002) and commercially available protein-synthesis manipulatives are excellent for helping kinesthetic learners. Additionally, Latourelle \& SeidelRogol (1998) provide a method for demonstrating DNA sequencing.

The effects of SCD are manifested in the quaternary structure of hemoglobin. Teachers can take advantage of the classroom activities to help students understand amino acid sequences and protein structure (Nelson \& Goetze, 2004; Asmus, 2007; Barber \& Maiers, 2007). In SCD, hemoglobin molecules bind to each other - rather than remaining independent molecules - as soon as oxygen levels decrease. Why? The story returns to protein synthesis. Sickle cell hemoglobin occurs as a result of thymine replacing adenine in the sixth codon of the beta-globin gene. This mutation causes nonpolar valine to replace the polar glutamic acid on the surface of the hemoglobin molecule. Under low-oxygen conditions, the valine interacts with a hydrophobic pocket (formed by 85 phenylalanine and 88 leucine) on another hemoglobin molecule. Thus, the molecules polymerize end-to-end, forming elongated macrostructures consisting of seven pairs of fibers (Ashley-Koch et al., 2000). The results of the mutation do not alter the ability of the hemoglobin to collect oxygen (Serjeant \& Serjeant, 2001). Instead, fewer erythrocytes are able to reach all areas of the body (DeRosa \& Wolfe, 1999).

\section{The Human Body}

The method of oxygen delivery can be taught with body systems and levels of organization (DeRosa \& Wolfe, 1999). McLaughlin (2001) describes how Web-based teaching tools can help students better understand the cardiovascular system. Oxygen deprivation in individuals with SCD can result in strokes and clots in various tissues and organs. Also, by causing sluggish blood flow, SCD increases the rate of bacterial infections, and this is potentially the most dangerous effect of SCD (Dispenzieri, 2001). Infection leads to the study of immunology.

\section{Medicine \& Scientific Investigation}

Medical technology is integrated into general biology. The interconnection of electrophoresis and SCD dates back to a 1949 issue of Science (Pauling et al., 1949). Advances in electrophoresis and the discovery of restriction enzymes (or endonucleases) enabled doctors to diagnose certain conditions. Embryonic DNA can be obtained through amniocentesis for prenatal diagnosis of SCD. The SCD and the beta-thalassemia mutations remove a restriction-enzyme (Mst II) cutting site (Chang et al., 1983). Therefore, DNA fragments are larger and travel more slowly in an electrophoretic matrix than normal hemoglobin.

Despite the ease of diagnosis, treatment with hydroxyurea, and repeated blood transfusions (along with chelation treatments), individuals with SCD suffer to some degree for the remainder of their lives. Currently, the only cure is a bone marrow transplant, but the limited number of compatible donors and the expense greatly limit this treatment (Claster \& Vichinsky, 2003).

A cure for SCD is one possible outcome of the current focus on embryonic stem cells (Chang et al., 2006). Research using transgenic mice to find cures for SCD allows teachers to make direct connections to the biotechnologies of recombinant DNA and gene therapy (McCune et al., 1994). The phrases "embryonic stem cells" and "transgenic organisms" ooze controversy, and there is little doubt that controversy leads to curiosity. Even though controversial, the "teachable moments" afforded by such intriguing topics should not be ignored.

Wefer (2003) described how the National Center for Biotechnology Information Web site (http://www.ncbi.nlm.nih.gov/) can be used to conduct BLAST searches for information related to diseases. That site links to the database OMIM (Online Mendelian Inheritance of Man), PubMed, structure databases, books, articles, and, in short, unlimited resources for students to find the latest medical and scientific information.

\section{Evolution, Natural Selection, \& Hemoglobin}

Using the kinetic activity of coloring enables students to follow the evolution of hemoglobin. Students see for themselves an interesting corollary between the evolution of the gene and the evolution of man (Zihlman $\&$ Simmons, 2001). The production of hemoglobin through the growth and development of humans also sheds light on a mechanism of evolution. Both the arrangement and expression of the alpha- and beta-globin genes move down a gene cluster arranged sequentially from 5' to 3'. Typically, epsilon is expressed during the first 3 months of embryonic development, gamma during fetal development, delta during childhood, and beta during childhood and adulthood. On the alpha-globin gene locus, zeta genes are expressed only during the first few weeks in the embryo, and alpha 1 and 2 genes thereafter. Some genes are not expressed and are therefore called "pseudogenes."

An understanding of natural selection will lead one to understand the continued existence of SCD. While current medical treatments have greatly improved the lives of patients within the developed world, students may wonder why the disease was ever able to become so common. The answer can be traced to the devastating effects of malaria. In some 
locales, sickle cell and malaria inflict opposing selection pressures homologous to stabilizing selection. When infected, those with SCT have fewer and less severe symptoms and recover faster. The SCD-malaria relationship was described for teachers by Barman et al. (1985). Perry (1993) used the relationship to discuss details of natural selection. Edlin (1990) examined it with regard to the concepts of species, race, and population. Because care must be taken to avoid negative stereotyping and misunderstanding, Lennox and Mikula (1977) developed a role-playing game that emphasizes the social and political concerns related to SCD.

\section{Malaria \& Bioethics}

According to the Centers for Disease Control and Prevention (CDC), an estimated 350-500 million cases of malaria, an infectious disease, occur each year, causing over 1 million deaths (CDC, 2007). The fatality rate for those with SCT is only 5\% the expected rate (Markell et al., 1999). An examination of those affected by malaria and SCT or SCD will reveal a higher incidence in some impoverished areas of the world. A teacher may choose to consider related ethical concerns. For example, a journal article concerning the use of DDT discusses the harmful ecological effects, but DDT is an excellent and inexpensive method of killing mosquitoes (Lewis, 2008). Using this real-world example, which requires them to consider the value of human life versus harmful environmental effects, may increase students' interest and hone their problem-solving skills (Mulvihill, 1996). Steinly (2004) describes a process, suitable for use on any campus, for conducting experiments related to mosquito reproduction and exploring the ramifications of pesticide use.

\section{$\bigcirc$ Participants' Assessments}

Nine female biology teachers with an average teaching experience of 16.5 years participated in the workshop. Four African-American and two Caucasian teachers taught at a high-minority school (95\% AfricanAmerican), and three white teachers taught at low-minority (21\% African-American) schools. Only four items were answered correctly by all teachers on the pretest. Three were related to the process of electrophoresis and the other classified hemoglobin as a protein. With a pretest mean of 16.57 (SD 2.0) and posttest mean of 23 (SD 1.4), the increase in knowledge was significant $(\mathrm{p}<0.01)$. On the posttest, all the teachers answered six items correctly: the original four plus two more. Six additional items were correctly answered by eight teachers.

All the teachers expressed interest in using similar themes within their own classrooms. For example, one teacher wrote that she expected to "gain some new knowledge" but got "a whole lot more." Futhermore, she wished that she "could do this tomorrow" and next she will "incorporate this into my lesson plans for next year." She added that "If you use a theme you can tie a good number of your lessons together, and in my opinion, the information will be better retained. When a student can connect thoughts together, they are harder to forget and they probably understand it better as well."

\section{O Discussion}

Evidence exists to support the use of themes in all types of classrooms (McComas \& Wang, 1998; Hurley, 2001) and, in particular, in biology classes (BSCS, 1993). Some researchers have demonstrated increased student achievement resulting from thematic instruction (Kovalik, 1994; Beane, 1997). Research into the physiological aspects of learning has suggested a benefit to education when the students are challenged to link ideas (Bransford et al., 1999). Other educators who promote the idea of brain-based education have found that the brain will better integrate new information when the new ideas have a connecting pattern (Hart, 1983). Most of the evidence to support thematic units is in the form of testimonials (Czerniak, 2007). Many educators, however, accept the practice on the basis of their own empirical evidence.
Surprisingly, all the teachers who participated were receptive to the idea of using sickle cell as a theme and were eager to incorporate more of these concepts in their classrooms. Another surprising result was the lack of knowledge about SCD among these seasoned biology teachers, as indicated by the pretest. This result reinforces our initial premise that, even though SCD is a ubiquitous topic, the information typically available in schools is obsolete and oversimplified.

An SCD unit can be adapted to meet the standards of each state. An SCD unit is a good example of how the teacher can take one topic and develop an in-depth unit study that incorporates mathematics applications, higher-level thinking skills, scaffolding, and technology. It also shows that one unit can meet the needs of visual, kinesthetic, and verbal learners. More importantly, the use of this or similar themes might serve to spark genuine interest and understanding in students.

\section{O Acknowledgments}

Funding for the materials used in the workshop was provided by the Mississippi EPSCoR grant EPS-0556308, Innovations through Computational Sciences, and the University of Southern Mississippi's Department of Biological Sciences.

\section{References}

Access Excellence @the National Health Museum. (No date). Desktop electrophoresis lab - Movinǵ molecules. Available at http://www.accessexcellence.org̈/ AE/AEPC/WWC/1993/movinģ.php.

Ashley-Koch, A., Yang, Q. \& Olney, R. (2000). Sickle hemoglobin (HbS) allele and sickle cell disease: a HuGE review. American Journal of Epidemioloģy, 151, 839-845.

Asmus, E.G. (2007). Protein structure. American Bioloğy Teacher, 69, 38-40.

Barber, R.D. \& Maiers, J. (2007). A "gुame" introduction to bioinformatic sequence comparison. American Biology Teacher, 69, 359-363.

Barman, C.R., Collins, A., Louis, E.J. \& Jungck, J.R. (1985). Sickle cell anemia: "Interesting pathology" and "rarely told stories." American Biology Teacher, 47, 183-187.

Beane, J.A. (1997). Curriculum Integration: Designing the Core of Democratic Education. Alexandria, VA: Association for Supervision and Curriculum Development.

Beutler, E., Lichtman, M.A., Coller, B.S., Kipps, T.J. \& Seligssohn, U. (2001). Williams Hematologgy, 6th Ed. New York, NY: McGraw-Hill.

Bloom, M. (1995). Understanding Sickle Cell Disease. Jackson, MS: University Press of Mississippi.

Bransford, J.D., Brown, A.L. \& Cocking, R.R., Eds. (1999). How People Learn: Brain, Mind, Experience, and School. Washington, DC: National Academy Press.

BSCS. (1993). Developing Biological Literacy: A Guide to Developing Secondary and Post-secondary Biology Curricula. Colorado Springss, CO: BSCS.

Centers for Disease Control and Prevention. (2007). Malaria facts. Available online at http://www.cdc.gov/malaria/about/facts.html.

Chang, J.C., Alberti, A. \& Kan, Y.W. (1983). A beta-thalassemia lesion abolishes the same Mst II site as the sickle mutation. Nucleic Acids Research, 11, 7789-7794.

Chang, J.C., Ye, L. \& Kai, Y.W. (2006). Correction of the sickle cell mutation in embryonic stem cells. Proceedings of the National Academy of Sciences, 103, 1036-1040.

Claster, S. \& Vichinsky, E.P. (2003). Manaģing sickle cell disease. British Medical Journal, 327, 1151-1155.

Czerniak, C. (2007). Interdisciplinary science teaching. In S.K. Abell \& N.G. Lederman (Eds.), Handbook of Research on Science Education. Mahwah, NJ: Lawrence Erlbaum Associates.

DeRosa, D.A. \& Wolfe, B.L. (1999). Mystery of the crooked cell. American Biology Teacher, 61, 137-148.

Dispenzieri, A. (2001). Sickle cell disorders. In A. Tefferi (Ed.), Primary Hematology (pp. 65-82). Totowa, NJ: Humana Press. 
Edlin, G. (1990). Reducing racial \& ethnic prejudice by presenting a few facts of genetics. American Biology Teacher, 52, 504-506.

Gordon, M.A. (2000). Let's Talk about Sickle Cell Anemia. New York, NY: PowerKids Press.

Hart, L.A. (1983). Human Brain and Human Learning. Village of Oak Creek, Arizona: Books for Educators.

Howe, E.M. (2007). Addressing nature-of-science core tenets with the history of science: an example with sickle-cell anemia and malaria. American Biology Teacher, 69, 467-472.

Hurley, M.M. (2001). Reviewing integrated science and mathematics: the search for evidence and definitions from new perspectives. School Science and Mathematics, 101, 259-268.

Kovalik, S. (1994). Integrated Thematic Instruction: The Model. Kent, WA: Susan Kovalik \& Associates.

Latourelle, S. \& Seidel-Rogol, B. (1998). A demonstration of automated DNA sequencing. American Biology Teacher, 60, 206-211.

Lederman, N.G. \& Niess, M.L. (1997). Integrated, interdisciplinary, or thematic instruction? Is this a question or is it questionable semantics? School Science and Mathematics, 97, 57-58.

Lennox, J.E. \& Mikula, A.R. (1977). The sickle cell: a simulation ģame. American Biology Teacher, 39, 238-239.

Lewis, K. (2008). DDT stalemate stymies malaria control initiative. Canadian Medical Association Journal, 179, 999-1000.

Lodewyk, K.R., Winne, P.H. \& Jamieson-Noel, D.L. (2009). Implications of task structure on self-regulated learning and achievement. Educational Psychology, 29, 1-25.

Mader, S.S. (1996). Bioloģy, 5th Ed. Dubuque, IA: Times Mirror Higher Education Group.

Markell, E.K., John, D.T. \& Krotoski, W.A. (1999). Medical Parasitology, 8th Ed. Philadelphia, PA: W.B. Saunders.

McComas, W.F. \& Wang, H.A. (1998). Blended science: the rewards and challenges of integrating the science disciplines for instruction. School Science and Mathematics, 98, 340-348.

McCune, S.L., Reilly, M.P., Chomo, M.J., Asakura, T. \& Townes, T.T. (1994). Recombinant human hemoglobins designed for gene therapy of sickle cell disease. Proceedings of the National Academy of Sciences, 91, 9852-9856.

McLaughlin, J.S. (2001). Breaking out of the box: teaching biology with web-based active learning modules. American Biology Teacher, 63, 110-115.

Mertens, T.R. \& Pursifull, J. (1986). The gुene scene: a human gुenetics ģame. American Biology Teacher, 48, 104-108.
Mulvihill, C. (1996). Making the chromosome-gुene-protein connection. American Biology Teacher, 58, 364-366.

Nelson, A. \& Goetze, J. (2004). Modeling protein folding \& applying it to a relevant activity. American Biology Teacher, 66, 287-289.

Offner, S. (1992). Teaching biology around themes: teach proteins \& DNA together. American Biology Teacher, 54, 93-101.

Pauling, L., Itano, H.A., Singer, S.J. \& Wells, I.C. (1949). Sickle cell anemia, a molecular disease. Science, 110, 543-548.

Perry, R.T. (1993). Using different examples of natural selection when teaching bioloģy. American Biology Teacher, 55, 241-244.

Segal, J.B., Strouse, J.J., Beach, M.C., Haywood, C., Witkop, C. \& Park, H.S. (2008). Hydroxyurea for the treatment of sickle cell disease. Evidence Report/Technology Assessment No. 165. (Prepared by Johns Hopkins University Evidence based Practice Center under contract No. 290-02-0018). AHRQ Publication No. 08-E007. Rockville, MD: Agency for Healthcare Research and Quality.

Serjeant, G.R. \& Serjeant, B.E. (2001). Sickle Cell Disease, 3rd Ed. Oxford, UK: Oxford University Press.

Starr, C. \& Tagggart, R. (1998). Biology: The Unity and Diversity of Life, 8th Ed. Belmont, CA: Wadsworth.

Steinly, B.A. (2004). The collection of mosquito eģs for classroom \& field investigations. American Biology Teacher, 66, 363-369.

Templin, M.A. \& Fetters, M.K. (2002). A working model of protein synthesis using Leģo building blocks. American Biology Teacher, 64, 673-678.

Vigue, C.L. (1987). Murphy's law and the human beta-globin gुene. American Biology Teacher, 49, 76-81.

Weatherall, D.J. \& Clegg, J.B. (2001). The Thalassaemia Syndromes, 4th Ed. Oxford, UK: Blackwell Science.

Wefer, S.H. (2003). Name that gene: an authentic classroom activity incorporating bioinformatics. American Biology Teacher, 65, 610-613.

Zihlman, A.L. \& Simmons, C. (2001). The Human Evolution Coloring Book. New York, NY: Harper Collins.

SHERRY S. HERRON (sherry.herron@usm.edu) is Associate Professor in the Department of Biological Sciences at the University of Southern Mississippi, 118 College Drive no. 5087, Hattiesburg, MS 39406-0001, where JOHN PARR (john.parr@usm.edu) is a graduate assistant and BRIDGETTE DAVIS (bridgette.I.davis@usm.edu) is an instructor. PARKER NELSON (parker.nelson@ hpsd.kl2.ms.us) is Assistant Principal at Hattiesburog High School, 301 Hutchinson Avenue, Hattiesburg, MS 39401.

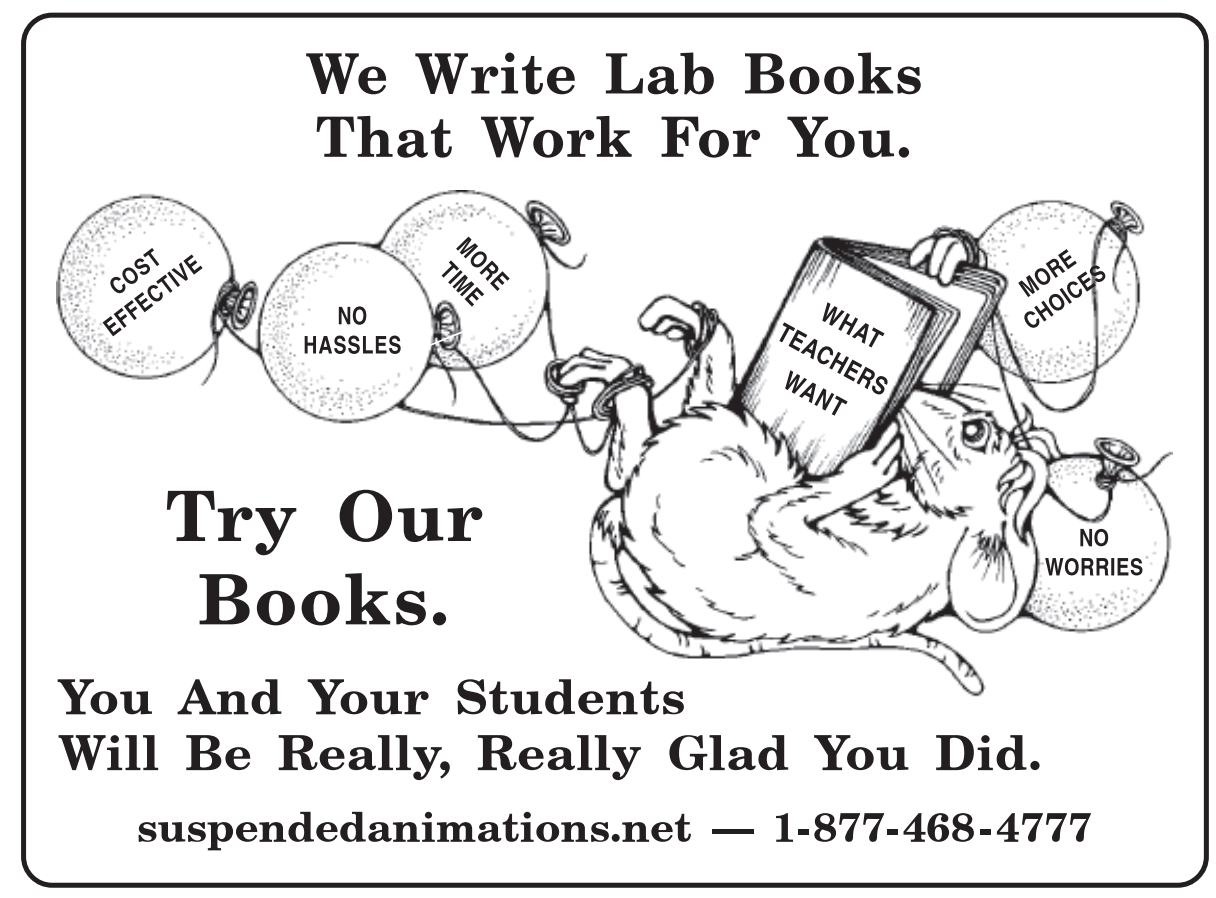

